\title{
COMPETITIVENESS OF COUNTRIES IN THE WORLD INNOVATION ECONOMY: CENTRAL-EASTERN EUROPE AND RUSSIA
}

\author{
IRINA RODIONOVA \\ Department of Regional Economy and Geography, Faculty of Economics, Peoples' Friendship University \\ of Russia, Moscow, Russia
}

Manuscript received: November 22, 2012

Revised version: May 7, 2013

Rodionova I., 2013. Competitiveness of countries in the world innovation economy: Central-Eastern Europe and Russia. Quaestiones Geographicae 32(2), Bogucki Wydawnictwo Naukowe, Poznań, pp. 15-24. 4 tables. DOI 10.2478/quageo-2013-0010, ISSN 0137-477X.

AвSTRACт. The positions of countries of Central and Eastern Europe as well as Russia are listed in ranking tables by aggregated indices which characterise the readiness of the countries to transfer their economies to innovative development. The connection between the use of information technologies and national economic development based on the innovative economy is established. The author characterises the positions of Russia and the new EU members in terms of international indices, including the Global Competitiveness Index.

KEY WORDS: competitiveness, innovation economy, Central and Eastern Europe, Russia

Irina Rodionova, Department of Regional Economy and Geography, Faculty of Economics, Peoples' Friendship University of Russia, Moscow, Miklukho-Maklaya str. 6, 117198, Moscow, Russia; e-mail: iarodionova@mail.ru

\section{The problem and research methodology}

The development of the latest technologies, the implementation of scientific achievements in production and the resultant increase in efficiency and other production quality indicators have affected the industrial composition of world manufacturing, directing it towards high-technology manufacturing industries (Rodionova 2009, Rodionova et al. 2010). Many countries have become more closely integrated with global chains of production of value added and industrial networks due to methods of ac- celerated technology transfer and faster access to sales markets.

In the recent decades the highest growth rates in the world industry as a whole and in the industries of advanced countries have been recorded in the production of communication facilities (radio, TV and communication equipment) as well as computer, office and electrical equipment. In the group of developing countries, the most intensive processes have occurred in China, Mexico, Brazil, India and other Asian countries of "new industrialisation" (with remarkable rates of development in sub-branches of mechanical engineering and the chemical industry). 
Thus, for example, in 1995 the main sectors of the world manufacturing industry were beverages and food $(11.8 \%)$ as well as chemicals and products of the chemical industry $(10 \%)$, but by 2010 the proportion of production of means of communication (radio, TV and communication equipment) had increased to $20.7 \%$ due to a sharp increase in the demand for them in the world market (Industrial Development Report 2011: 144). Today this sector is the leader in the industrial composition of the world manufacturing industry.

According to forecasts, in advanced countries technological systems with adaptive management and self-training technological systems will be practised on a wide scale, and there will be methods of permanent designing of cars and production systems with rules of self-organised production. The role of high-efficiency knowledge-intensive equipment will increase if competitive production is organised.

This article is part of a series by the same authors. Previously we characterised Russia's position in international rankings (Rodionova et al. 2010) and in comparison with the CIS countries ${ }^{1}$ where it is still an obvious leader (Rodionova \& Gordeeva 2010, 2011). In this article Russia's position is compared against the countries of Central and Eastern Europe (CEE) - the new EU members, which were previously behind Russia by all economic indicators.

It is necessary to remember that there were complicated processes in the recent years in the zone of influence of the former Soviet Union, especially in the economies of East-Central Europe (Poland, Hungary, the Czech Republic, etc.) and the CIS countries (including Russia), where economic restructuring involving the transition "from plan to market" was carried out, and transformation processes still proceed. Several East European countries have managed to overcome the crisis, inter alia due to joining the European Union, and to change considerably the model of their participation in the global economy. At the same time it should be noted that over the past 20 years Russia and other CIS countries have failed to carry out a structural transformation of their economies towards knowledge-intensive branches and information technologies. And though Russia's resource-based export policy is quite effective in generating high indicators of economic growth given the current high prices of energy, in a long-term prospect it is pernicious for the national economy. The natural resource potential as a whole and especially the fuel and energy resources are not renewable.

Therefore the development of new and the modernisation of existing tools and mechanisms of implementing innovative technologies in industrial production, enhancing the innovative activity of organisations, state support for the hi-tech sector of the economy, attracting financial resources, as well as the distribution of hi-tech products of Russia, Poland and other East-Central European countries to the world market are highly topical issues.

The research relies on the information of prestigious international publications and analytical reports of the World Bank, the World Economic Forum, and research papers. Its theoretical basis is supplied by the numerous works of domestic and foreign authors devoted to the analysis of problems and tendencies in the development of the countries of East-Central Europe and the former USSR after the disintegration of the socialist system in the transition period of their economies in the years 1990-2000. Thus, for example, in its Transition Report 2004, the European Bank for Reconstruction and Development (EBRD) seeks to foster the transition to an open market-oriented economy and to promote private and entrepreneurial initiative in East-Central Europe and the Baltic states, South-Eastern Europe and the Commonwealth of Independent States. To perform this task effectively, the Bank had to analyse and understand the process of transition. The purpose of the Report is to advance this understanding and to share its analysis with its partners. Articles about the situation in this region, published in such foreign journals as Economics of Transition

CIS, or the Commonwealth of Independent States, is the free association of sovereign states formed in 1991 by Russia and 11 other republics that were formerly part of the Soviet Union. 
or Beyond Transition Newsletter and others, are of great scientific interest. ${ }^{2}$

Many authors have written about this fact. The transition from socialism to a market economy has transformed the lives of many people. Young people take a much more favourable view of it than older people. And there is a robust support for both democracy and the market economy. Young people tend to support these trends the most. However, major challenges lie ahead, even in some of the most advanced countries of the region, including a strong urban/rural divide and scarcer private-sector services in rural areas. And politicians face a particularly strong challenge in raising the level of public trust in institutions, such as the government and parliament, and in fighting corruption (Sanfey et al. 2007).

Human development indicators underwent wide swings during and after the crisis, correlating strongly with movements in income. The authors of one of articles detected significant differences among countries in terms of human development responses to income shocks. "Researchers attribute a good part of this variation to differences in cushions to income (e.g., accumulated wealth, uncorrelated shadow economy income) and the efficiency of the social safety net. The results suggest that the unfolding impact of the global crisis is shaping up to be substantial, lasting, and particularly adverse for disadvantaged regions and social groups. Thus, the crisis is likely to cause a substantial setback to progress achieved so far towards improving human development indicators" (Horváth et al. 2009).

The Regional Human Development Report on Social Inclusion (2011) presents an integrated conceptual framework for social inclusion and human development. It puts forth a new measure for analysing social exclusion that goes beyond income, thus offering a more comprehensive perspective. It integrates individual risks, drivers, and local context to create a policy-relevant tool for assessing social exclusion and its causes. Economic growth has not always translat-

Economics of Transition, the European Bank for Reconstruction and Development. http:/ / onlinelibrary. wiley.com>journal/10.1111/(ISSN) (accessed 27 July 2012). Beyond Transition, The Newsletter about Reforming Economies. http://www.worldbank.org/transitionnewsletter (accessed 27 July 2012). ed into increased job opportunities, improved social services or greater opportunities for civil participation. Despite the region's heterogeneity in growth and development levels, the intensity of social exclusion is similar across countries. Large parts of the population have not been able to adapt to the new demands of the labour market. It is a very interesting conclusion. The report also points out that governments play an instrumental role in the process of social exclusion and inclusion. During transition the state underwent a significant transformation 'on the run'. As a result, state responsibilities shrank considerably, but this left huge grey areas without a clear division of labour among government, emerging civil society, and the business sector. This led to weak governance, law enforcement and, in some countries, entrenched corruption - all serving to foster social exclusion. The changing views on the role of the state contribute to policy swings that diminish the efficiency of social inclusion interventions.

One of the most in-depth studies, in our opinion, is the three-language report Central and Eastern Europe in the second half of the 20th centu$r y$, which states that the transformation-related recession of the early 1990s was less deep in the CEE countries than in Russia and the social and economic situation in most of them is now better than in Russia (Nekipelov et al. 2000-2002). It especially concerns Slovenia, the Czech Republic, Hungary and Poland. In those countries economic growth began in 1992-1994. It is often emphasised that the history of the CEE countries is inseparably linked with their participation in various regional associations or unions. Since 1949 they were members of the Council for $\mathrm{Mu}$ tual Economic Aid (CMEA), and their way to the European Union began after the collapse of the socialist system. Financial help was already rendered to the CEE states during their preparation for EU membership and increased after they had joined the Union. 200 billion euro out of the 862 billion of the total EU budget for the years 2007-2013 are earmarked for the development of the new member states, about 60 billion euro going to Poland (Orlik 2009). In other words, the accession to the EU has become a powerful incentive for economic growth of the CEE states. But EU membership does not mean an automatic 
solution of the complex of problems of the countries of this region. Many researchers note that it is premature to speak about a fast achievement of the level of the advanced European countries by new members. "The problem of achievement of the level of competitiveness of the developed European states remains an issue of the future for the new members of the EU, as its decision is connected with overcoming a considerable backlog in the degree of stability of economic and institutional development, in the level of its efficiency and innovativeness" (Glinkina 2007).

Researchers characterise the influence of the recent world crisis on the economies of the new EU members. The aim of this work is to assess the impact of financial crises on the output of 11 European transition economies (CEECs). "The main results of the paper can be summarised as follows: 1. Financial crises have a significant impact on output both in the short and in the long run. In particular, financial crises are found to lower output by 1 percent after one year and by 12-17 percent after 5 years. 2 . Comparing the effect of financial crises between the CEECs and the EU-15 economies, the results suggest that the effect is greater for the CEECs. 3. (...) The impact of financial crises is larger for smaller countries, in which the banking sector shows greater disequilibria. 4. The impact of financial crises on growth performance is mostly influenced by fiscal policy (in terms of increases in government spending), whereas the effect of monetary policy is rather modest. Flexible exchange rates attenuate the impact of the crises in the short to medium term, but tend to amplify the effect in the long run. Finally, foreign financial aid (in terms of IMF credit and loans) is found to attenuate the effect of the crises in the long run" (Furceri \& Zdzienicka 2011).

It is also worth noting other works by Russian and foreign scholars (Philipov \& Dorbritz 2003, Kopytina 2007, Klugman \& Scott 2009, Hagemejer \& Tyrowicz 2012, Lehmann \& Muravyev 2012, etc.).

The fundamental economic and social reforms in the transition countries are among the most important ones that the world has experienced. Researchers note that in many ways the transition has enabled people to broaden their choices in ways that were never possible under the old regime, but the reforms have also brought huge challenges. The region was broadly characterised by good development outcomes relative to incomes, especially in poorer countries. However, throughout the region, the early years of transition saw tremendous socio-economic hardship. Since then, some economies have experienced a significant bounce-back which started earlier in such countries as Poland, Slovakia, and Slovenia. Three countries in particular, Moldova, the Russian Federation and Tajikistan, which experienced human development setbacks in the 1990s, are still behind their HDI of 1990, even before incorporating the data reflecting the impact of the recent economic crisis (Klugman \& Scott 2009).

The focus of this article is on some development aspects of the countries of the region. Its purpose is to reveal modernisation problems their economies meet on the way to innovative development. An attempt is made to understand what has to be undertaken to make the countries closer to the world leaders by formulating their own innovative paradigms of national development.

The methodology employed in the research involves the use of some international rankings which reflect the readiness of the countries for the knowledge-based economy and the level of advancement of their ICT sectors. Their representativeness is assessed and calculations are made of the correlation between the indices of the countries in the international ratings and the level of their economic development. Five indicators are employed: Gross Domestic Product per capita, Gross Domestic Product per person employed, gross domestic expenditure on R\&D (GERD) per capita, gross value added of high-technology manufacturing industries per capita, and the production and services of the ICT sector per capita. A comparison is made of the positions of the world leaders, CEE states and Russia in the international ratings.

\section{Calculation of correlation ratios}

There are several complex indicators (aggregated indices) characterising the level of development of the economy based on knowledge. They show what distinguishes countries in terms of innovation and information and computer 
technologies (ICT). In order to show the influence of ICT on economic growth and development of the countries, correlation ratios between pairs of indicators were calculated.

It was found that there was a direct correlation between all the indices employed: the Knowledge Economy Index (KEI), Networked Readiness Index (NRI), Information Society Index, and Global Innovation Index (GII). For the year 2012, the correlation between all the indices and per capita GDP of the countries was $0.86-0.92$; between the indices and their gross domestic expenditure on R\&D (GERD) per capita, 0.81-0.91; between the indices and their GDP per employee, 0.80-0.85; between the indices and value added of their high-technology manufacturingindustries industries per capita, 0.53-0.70; and between the indices and their ICT production and services per capita, 0.79-0.88. First, this indicates integral indices to be highly representative. Secondly, it shows that nowadays only countries highly advanced in socio-economic development are prepared for a network economy (the knowledge economy and widespread use of ICT). Thirdly, it indicates that the leaders in world hi-tech production are those countries that put knowledge and ICT to advantage for their economies.

The countries well advanced in ICT development have great results in enhancing the welfare of their citizens (per capita GDP). However, this effect appears only when a country reaches a certain level of ICT use in directing its socio-economic development.

\section{Positions of Russia and CEE states in international rankings of innovative economies}

\subsection{Knowledge Economy Index}

The Knowledge Economy Index is calculated with the help of the knowledge assessment methodology developed by the World Bank to characterise the ability of countries to create, accept and extend knowledge (Knowledge Economy Index 2012). Table 1 shows the 2012 values of the Knowledge Economy Index and its pillars, including the Knowledge Index.

The analysis of the data presented in Table 1 shows the positions of the new EU members and Russia to be not too high in the world ranking (by the Knowledge Economy Index, from 19th to 55th out of 145). It also reveals their places against other countries by the pillars of aggregated indices (including such important ones as innovations, education, and information and communication technologies). The best positions among the CEE countries go to Estonia (19th). Poland (38th) is behind the Czech Republic (26th), Hungary

Table 1. Knowledge Economy Index and its pillars, 2012.

\begin{tabular}{|c|c|c|c|c|c|c|c|}
\hline \multirow[b]{2}{*}{ Rank } & \multirow[b]{2}{*}{ Country } & \multirow{2}{*}{$\begin{array}{l}\text { Knowledge } \\
\text { Economy } \\
\text { Index }\end{array}$} & \multirow{2}{*}{$\begin{array}{c}\text { Knowledge } \\
\text { Index }\end{array}$} & \multicolumn{4}{|c|}{ Pillars } \\
\hline & & & & $\begin{array}{l}\text { Institutional } \\
\text { factors }\end{array}$ & Innovations & Education & ICT \\
\hline 1 & Sweden & 9.43 & 9.38 & 9.58 & 9.74 & 8.92 & 9.49 \\
\hline 2 & Finland & 9.33 & 9.22 & 9.65 & 9.66 & 8.77 & 9.22 \\
\hline 3 & Denmark & 9.16 & 9.00 & 9.63 & 9.49 & 8.63 & 8.88 \\
\hline 4 & Netherlands & 9.11 & 9.22 & 8.79 & 9.46 & 8.75 & 9.45 \\
\hline 5 & Norway & 9.11 & 8.99 & 9.47 & 9.01 & 9.43 & 8.53 \\
\hline \multicolumn{8}{|c|}{$\ldots$} \\
\hline 26 & Czech Republic & 8.14 & 8.00 & 8.53 & 7.90 & 8.15 & 7.96 \\
\hline 27 & Hungary & 8.02 & 7.93 & 8.28 & 8.15 & 8.42 & 7.23 \\
\hline 28 & Slovenia & 8.01 & 7.91 & 8.31 & 8.50 & 7.42 & 7.80 \\
\hline 38 & Poland & 7.41 & 7.20 & 8.01 & 7.16 & 7.76 & 6.70 \\
\hline \multicolumn{8}{|c|}{$\ldots$} \\
\hline 19 & Estonia & 8.40 & 8.26 & 8.81 & 7.75 & 8.60 & 8.44 \\
\hline 32 & Lithuania & 7.80 & 7.68 & 8.15 & 6.82 & 8.64 & 7.59 \\
\hline 37 & Latvia & 7.41 & 7.15 & 8.21 & 6.56 & 7.73 & 7.16 \\
\hline \multicolumn{8}{|c|}{$\ldots$} \\
\hline 55 & Russia & 5.78 & 6.96 & 2.23 & 6.93 & 6.79 & 7.16 \\
\hline
\end{tabular}

Source: compiled on the basis of Knowledge Economy Index (2012). 
and Slovenia, while Lithuania (32nd) and Latvia (37th) follow Italy and Malta, but also precede Poland.

Russia falls behind many countries of East-Central Europe, including Slovakia, Croatia, Romania, Bulgaria and Serbia. At the same time many CIS countries are placed even lower (from 56th - Ukraine, to 106th - Tajikistan). Russia and the other CIS countries have low indicators in the following pillars of the index: institutional factors, innovations, and use of information technologies.

In the 2012 international ranking by the Global Innovation Index (GII), the positions of the new EU members were the following: Estonia 19th, Slovenia - 26th, the Czech Republic - 27th , Latvia - 30th , Hungary - 31st, Lithuania - 38th, Poland -44 th, and Russia - 51st.

\subsection{Networked Readiness Index}

At the World Economic Forum in 2001 a strong connection was noted between the implementation of information and communication technologies and economic prosperity of a state. Since then countries have been ranked annually in terms of the Networked Readiness Index
(NRI) on a 7-point scale (Networked Readiness Index 2012). Let us characterise the positions of the leading countries, the developing countries with the highest growth rates in East-Central Europe, and Russia (Table 2).

It should be noted that there were considerable changes between the ranking by the Networked Readiness Index in 2009 and in 2012. Also, the number of analysed countries increased from 134 to 142 . In the group of leaders only small shifts can be noted over this period. Nevertheless, the USA fell from 3rd to 8th position, while Singapore went two places up and became 2nd after Sweden.

Among the states of East-Central Europe, the leading position in the 2012 rating is taken by Estonia (24th). Lithuania (31st) and Latvia (41st) have quite high positions too. It is worth noting that Poland considerably strengthened its position, moving up from 69th to 49th place. In the 2009 ranking it followed Romania, Brazil, Turkey and Mexico; today Poland is much above these and many other countries in the ranking.

Among the CIS countries Kazakhstan moved up from 73rd to 55th position, still slightly in advance of Russia with its 56th place (74th in 2009). It should also be noted that China precedes all CIS countries in this ranking, placed as 51st.

Table 2. Ranking of countries by the Networked Readiness Index (NRI).

\begin{tabular}{|c|c|c|c|c|c|}
\hline \multicolumn{3}{|c|}{ 2008-2009 } & \multicolumn{3}{|c|}{2012} \\
\hline Rank & Country & NRI & Rank & Country & NRI \\
\hline 1 & Denmark & 5.85 & 1 & Sweden & 5.94 \\
\hline 2 & Sweden & 5.84 & 2 & Singapore & 5.86 \\
\hline 3 & USA & 5.68 & 3 & Finland & 5.81 \\
\hline 4 & Singapore & 5.67 & 4 & Denmark & 5.70 \\
\hline 5 & Switzerland & 5.58 & 5 & Switzerland & 5.61 \\
\hline \multicolumn{6}{|c|}{$\ldots$} \\
\hline 31 & Slovenia & 4.57 & 37 & Slovenia & 4.62 \\
\hline 32 & Czech Republic & 4.53 & 42 & Czech Republic & 4.33 \\
\hline 41 & Hungary & 4.28 & 43 & Hungary & 4.30 \\
\hline 69 & Poland & 3.80 & 49 & Poland & 4.16 \\
\hline \multicolumn{6}{|c|}{$\ldots$} \\
\hline 18 & Estonia & 5.19 & 24 & Estonia & 5.09 \\
\hline 35 & Lithuania & 4.40 & 31 & Lithuania & 4.66 \\
\hline 48 & Latvia & 4.10 & 41 & Latvia & 4.35 \\
\hline \multicolumn{6}{|c|}{$\ldots$} \\
\hline 74 & Russia & 3.77 & 56 & Russia & 4.02 \\
\hline
\end{tabular}

Source: compiled on the basis of Networked Readiness Index 2008-2009 and 2012. 


\subsection{Global Competitiveness Index}

Let us also characterise the positions of the CEE countries and Russia in the ranking in terms of the Global Competitiveness Index calculated for 139 countries (2010-2011) and 144 countries (2012-2013), where indicators of the aggregated index are converted on a scale of 1 to 7 (the GCI characterises three main sub-indexes: basic requirements, efficiency enhancers, and innovation and sophistication factors). The World Economic Forum defines competitiveness as the set of institutions, policies, and factors that determine the level of productivity of a country. It is emphasised that more competitive countries can ensure their citizens higher levels of income (Global Competitiveness Report 2011-2012: 4). Information about the positions of the leading states and the countries of East-Central Europe in the international GCI ranking is presented in Table 3.

The Global Competitiveness Index consists of 113 variables (12 pillars) which characterise in details the competitiveness of countries. It is important to note that no factor separately is able to improve or ensure high competitiveness to any economy. The effect of an increase in expenditure for education can be reduced, for example, by the inefficiency of the labour market, etc. Or there will be no good results if graduates are not employed in an appropriate way. Further, attempts to optimise control over public finance will be successful only in the absence of corruption, transparency of the financial system control, etc. It is important to consider the fact that business people will start to invest in research and development and to introduce new technologies in production only if the potential profit exceeds essential investments, etc. (Global Competitiveness Report 2010-2011).

Let us now compare the positions of countries in the GCI rankings in 2010-2011 and 2012-2013. In both periods, at the very beginning of the rating table, that is, in the group of leaders, there are still Switzerland, Singapore, Sweden, Finland, the USA, Germany, and other developed countries. In 2010-2011, Russia was on 63rd position. The Czech Republic and Poland were higher up 36th and 39th, while Estonia and Lithuania, 33rd and 47 th, respectively. On average, the figures for all CEE countries lag behind the OECD ones (the index of the OECD countries was 4.9 out of 7 points, Russia -4.2 , Poland -4.5 and the Czech Republic - 4.6). There was some improvement before the world financial crisis (in comparison with the 2008 GCI ranking), but in the post-crisis period the positions of those countries worsened a little (Report about the competitive power of Russia 2011: 17). Thus, according to the 2012-2013 Global Competitiveness Report, Estonia takes 34th position now, the Czech Republic - 39th, Poland - 41st,

Table 3. Ranking of countries by the Global Competitiveness Index (GCI).

\begin{tabular}{|c|c|c|c|c|c|}
\hline \multicolumn{3}{|c|}{$2010-2011$} & \multicolumn{3}{|c|}{ 2012-2013 } \\
\hline Rank & Country & GCI & Rank & Country & GCI \\
\hline 1 & Switzerland & 5.63 & 1 & Switzerland & 5.72 \\
\hline 2 & Sweden & 5.56 & 2 & Singapore & 5.67 \\
\hline 3 & Singapore & 5.48 & 3 & Finland & 5.55 \\
\hline 4 & USA & 5.43 & 4 & Sweden & 5.53 \\
\hline 5 & Germany & 5.39 & 5 & Netherlands & 5.50 \\
\hline \multicolumn{6}{|c|}{$\ldots$} \\
\hline 36 & Czech Republic & 4.57 & 39 & Czech Republic & 4.51 \\
\hline 39 & Poland & 4.51 & 41 & Poland & 4.46 \\
\hline 45 & Slovenia & 4.42 & 56 & Slovenia & 4.34 \\
\hline 52 & Hungary & 4.33 & 60 & Hungary & 4.30 \\
\hline \multicolumn{6}{|c|}{$\ldots$} \\
\hline 33 & Estonia & 4.61 & 44 & Estonia & 4.64 \\
\hline 47 & Lithuania & 4.38 & 45 & Lithuania & 4.41 \\
\hline 70 & Latvia & 4.14 & 55 & Latvia & 4.35 \\
\hline \multicolumn{6}{|c|}{$\ldots$} \\
\hline 63 & Russia & 4.24 & 67 & Russia & 4.20 \\
\hline
\end{tabular}

Source: compiled on the basis of Global Competitiveness Reports 2010-2011 and 2012-2013. 
IRINA RODIONOVA

Table 4. Pillars of the 2010-2011 Global Competitiveness Index (GCI): Russia, Poland, Czech Republic.

\begin{tabular}{|l|c|c|c|c|c|c|}
\hline \multirow{2}{*}{ Pillars of the Global Competitiveness Index } & \multicolumn{2}{|c|}{ Russia } & \multicolumn{2}{c|}{ Poland } & \multicolumn{2}{c|}{ Czech Republic } \\
\cline { 2 - 7 } & Rank & Index & Rank & Index & Rank & Index \\
\hline Global Competitiveness Index 2010-2011 & 63 & 4.2 & 39 & 4.5 & 36 & 4.6 \\
\hline Basic requirements & 65 & 4.5 & 56 & 4.7 & 44 & 4.9 \\
\hline Pillar 1: Institutions & 118 & 3.2 & 54 & 4.2 & 72 & 3.9 \\
\hline Pillar 2: Infrastructure & 47 & 4.5 & 72 & 3.8 & 39 & 4.8 \\
\hline Pillar 3: Macroeconomic environment & 79 & 4.5 & 61 & 4.7 & 48 & 4.9 \\
\hline Pillar 4: Health and primary education & 53 & 5.9 & 39 & 6.1 & 43 & 6.1 \\
\hline Efficiency enhancers & 53 & 4.2 & 30 & 4.6 & 28 & 4.7 \\
\hline Pillar 5: Higher education and training & 50 & 4.6 & 26 & 5.0 & 24 & 5.1 \\
\hline Pillar 6: Goods market efficiency & 123 & 3.6 & 45 & 4.4 & 35 & 4.6 \\
\hline Pillar 7: Labour market efficiency & 57 & 4.5 & 53 & 4.6 & 33 & 4.7 \\
\hline Pillar 8: Financial market development & 125 & 3.2 & 32 & 4.7 & 48 & 4.5 \\
\hline Pillar 9: Technological readiness & 69 & 3.6 & 47 & 4.0 & 32 & 4.5 \\
\hline Pillar 10: Market size & 8 & 5.7 & 21 & 5.1 & 42 & 4.5 \\
\hline Innovation and sophistication factors & 80 & 3.4 & 50 & 3.8 & 30 & 4.2 \\
\hline Pillar 11: Business sophistication & 101 & 3.5 & 50 & 4.2 & 22 & 5.4 \\
\hline Pillar 12: Innovation & 57 & 3.2 & 54 & 3.3 & 27 & 3.9 \\
\hline
\end{tabular}

Source: compiled on the basis of Report about the competitive power of Russia (2011: 115-117, 175-177 and 203-205).

Lithuania - 45th, Latvia - 55th, Slovenia - 56th, and Russia has fallen from 63rd to 67th place. It is worth noting that China has already risen to 29 th position, being considerably in advance of Russia and other CEE countries by many indicators under analysis.

It might be interesting to examine the data on the individual pillars of the GCI and the positions that Russia, the Czech Republic and Poland occupy by each of them (Table 4).

What factors made the most considerable impact on the development of the CEE countries and Russia in the last two decades, and what are the reasons of so different positions of these states in the international ratings? Success in ICT development in the individual CEE countries, in our opinion, is connected, first, with the existence of a private sector in those states already before 1990 when they started transforming their economies at faster rates. In Russia the conditions were absolutely different after the 70-year period of socialist development and a planned economy; moreover, there was inaction of institutions and society that disturbed changes. Secondly, an important factor was a favourable economic and geographical position of the countries of this region (proximity to the advanced countries of Western Europe, first of all to Germany), as well as their transit location on the way of trading streams from Russia and other CIS countries to Europe. Thirdly, their accession to the EU had a positive influence, considering the fact that they had prepared for it some years previously and have since received (and still do) significant financial assistance from the more developed EU members. Fourthly, most of capacities of multinational corporation branches moved from Western Europe to CEE, where labour costs were much lower and labour qualifications quite good. All this allowed those countries to reach considerable growth rates of production. As a result, after 20 years of the transformation, the CEE states (first of all the Czech Republic, Hungary and Poland) have integrated with the world and European economies more successfully than Russia. The list of factors which have influenced the development of the economy can certainly be continued.

\section{Conclusions}

Today the ICT sector plays a fundamental role in world production and the introduction of innovation. By raising productivity and competitiveness, its technologies promote economic diversification and stimulate business activity. ICT development in the post-socialistic countries of the East-Central Europe and the CIS still lags behind the level of ICT use in advanced countries, and this affects their positions in international rankings.

The main advantages of Russia and the CEE countries - new EU members in ICT develop- 
ment are their high indicators of elementary education and the proportion of population with secondary and higher education. But the countries of East-Central Europe (the Czech Republic, Hungary, Poland, Slovenia, Estonia, Lithuania, Latvia and others) are faster in their transition to a knowledge-based economy than Russia and other CIS states (which is shown by their high positions in the world rankings). Even so, the competitiveness of companies and production of these states is still much lower than in the developed countries.

Russia and the new EU members have serious plans for improvement of the structure of their economies and the transition to an innovative way of development. The implementation of effective innovation and investment policies will allow Russia and those countries to take more rightful places in the global economy during the post-crisis period and later. In the modern world, stable innovative development is impossible without carefully thought-out innovation and investment policies and the minimisation of the influence of external and internal risks. Innovative development is a promise of strengthened economic power at all levels.

\section{References}

Furceri D. \& ZDZIENICKA A. 2011. The real effect of financial crises in the European transition economies. Economics of Transition, 19(1): 1-25. From http:// onlinelibrary.wiley. com/journal/10.1111/\%28ISSN\%291468-0351 (accessed 27 July 2012).

GLINKINA S., 2007. East-Central Europe on the way to EU (in Russian). Novaia i noveishaia istoriia, 3.

Global Competitiveness Report 2011-2012. World Economic Forum, Geneva, 2011. From http:/ / www.weforum.org/ issues/global-competitiveness (accessed 7 July 2012).

Global Competitiveness Report 2012-2013. World Economic Forum, Geneva, 2012. From http:/ / www.weforum.org/ issues/global-competitiveness (accessed 10 Jan. 2013).

Global Innovation Index 2012: Stronger innovation linkages for global growth. INSEAD (Business School for the World) and the World Intellectual Property Organisation (WIPO). From http://www.globalinnovationindex.org/ gii/ (accessed 7 July 2012).

Hagemejer J. \& Trrowicz J., 2012. Is the effect really so large? Firm-level evidence on the role of FDI in a transition economy. Economics of Transition, 20(2): 195-233. From http:// onlinelibrary.wiley.com/ journal/10.1111/\%28I SSN\%291468-0351/ (accessed 27 July 2012).

Horváth B., Ivanov A., Peleah M. \& Pospíšllová M., 2009. Losing the gains: How the crisis will impact human development in the region. Development $\mathcal{E}$ Transition,
14: 4-6. From http://europeandcis.undp.org/data/ show/6E8867C4-F203-1EE9-B7B44D608FB52E93 (accessed 27 July 2012).

Industrial Development Report, 2011. Industrial energy efficiency for sustainable wealth creation. UNIDO, Vienna. From http://www.unido.org/index.php?id=1002049 (accessed 27 July 2012).

Klugman J. \& ScotT T., 2009. Twenty years of transition and human development: an appraisal. Development $\mathcal{E}$ Transition, 14: 17-19. From http://_europeandcis.undp. org/ data/show/D0D2548E-F203-1EE9-B1D3BDF5CD36C0DE (accessed 24 Sept. 2012).

Knowledge Economy Index, 2012. The World Bank Group, Knowledge for Development. From http://info.worldbank.org/etools/kam2/KAM_page5.asp. (accessed 7 July 2012).

Kopytina M. (ed.), 2007. Economic and humanitarian cooperation of Russia and Czech Republic: new prospects. Economy Institute, Russian Academy of Sciences, Moscow. From http:/ / www.imepi-eurasia.ru/ kalendar.php?id=253 (accessed 24 Sept. 2012).

Lehmann H. \& Muravyev A., 2012. What can we learn from transition countries? Labour market institutions and labour market performance. Economics of Transition, 20(2): 235-269. From http://onlinelibrary.wiley.com/journal/10.1111/\%28ISSN\%291468-0351 (accessed 27 July 2012).

Nekipelov A., Glinkina S., Grinberg R. and others (eds), 2000-2002. Central and Eastern Europe in the second half of the 20th century. Institute of International Economic and Political Research, Russian Academy of Sciences. Nauka, Moscow.

Networked Readiness Index 2008-2009. The Global Information Technology Report 2008-2009. From http://gtmarket.ru/news/state/2009/04/05/2477 (accessed 10 Jan. 2013).

Networked Readiness Index 2012. The Global Information Technology Report 2012. From http://www.weforum. org/issues/global-information-technology/gitr-2012data-platform (accessed 7 July 2012).

ORLIK I., 2009. East-Central Europe: from the Council for Mutual Economic Assistance to the European Union. New and contemporary history, 2. From http:// www.perspektivy.info/ rus/desk/centralno-vostochnaja_ jevropa ot_sev_do_ jevrosojuza_ 2010-07-12.htm (accessed 7 July 2012).

Philipov D. \& Dorbritz J., 2004. Demographical consequences of economic transition in countries of Central and Eastern Europe. Council of Europe Publishing (Population Studies 39), Strasbourg. From http:/ / www.coe.int/ T/E/Social_ Cohesion/ Population/ Pop39\%20Demo\%20conseq $\% 20$ c\&e\%20eng.pdf (accessed 27 July 2012).

Regional Human Development Report on Social Inclusion, 2011. Beyond Transition - Towards Inclusive Societies. UNDP Regional Bureau for Europe and CIS, Bratislava. From http://www.slideshare.net/undpeuropeandcis/ beyond-transition-towards-inclusive-societies-regional-human-development-report-2011 (accessed 24 Sept. 2012).

Report about the competitive power of Russia, 2011. Committed to improving the state of the world. World Economic Forum.

RodionOva I., 2009. World industry: structural shifts and trends of development (in the second half of the 20th century and the beginning of the 21st century). Moscow State Forest University, Moscow. 
Rodionova I. \& Gordeeva A., 2010. Human Development Index and informatisation of society in the CIS. Bulletin of Geography, 13: 79-87.

Rodionova I. \& GordeEva A., 2011. The role of information technologies in controlling the economic development of countries. Upravlenets, 7-8: 18-21, Ekaterinburg.

Rodionova I., Gordeeva A. \& Kokuytseva T., 2010. New technologies: increasing role in the competitiveness of world countries. Izvestia of Ural State Economic University, 5: 119-125.
Sanfey P., Steves F. \& Teksoz U., 2007. Life in transition: Current attitudes. Beyond Transition. The Newsletter About Reforming Economies, 18(2) 21-22. From http://www.econ. brown.edu/fac/Ross_Levine/Publication/2007_BeyondTransition_financeandopportunity.pdf (accessed 24 Sept. 2012).

Transition report 2004. Infrastructure. European Bank for Reconstruction and Development, London. From www. ebrd.com/ (accessed 7 July 2012). 